\title{
The Effect of Economic Determinants on Capital Structure with Market Conditions as a Control Variable (Case Study of IDX- Listed LQ 45 Manufacturing Company in 2015-2019)
}

\author{
Theresalin, I Gusti Ketut Agung Ulupui, Harya Kuncara \\ Faculty of Economics, Jakarta State University, Indonesia \\ Email: theresalin1061@gmail.com, igka-ulupui@unj.ac.id, har_kun@unj.ac.id
}

\begin{abstract}
ARTICLE INFO
Received: 08-01-2022

Revision: 13-01-2022

Received : 20-01-2022

Keywords:

Capital Structure;

profitability;

company size; company

growth; asset structure;

liquidity; effective tax

rate;

business risk; multiple

regression

\section{ABSTRACT}

This study aims to examine the effect of economic determinants on Capital Structure as measured by Profitability, Company Size, Company Growth, Asset Structure, Liquidity, Effective Tax Rate, Business Risk in LQ 45 Manufacturing Companies Listed on the IDX in the 2015 - 2019 Period. The information used in this study came from the company's annual report, which was made available to the public via the Indonesia Stock Exchange or the company's website. Purposive sampling was employed, with a total sample size of 135 samples. Multiple linear regression analysis was utilized to analyze the data in this study. Classic assumption testing, such as descriptive analysis, chow test, Hausman test, LM test, data normality, heteroscedasticity, multicollinearity, and autocorrelation, had previously been performed on the data. The research data were found to be regularly distributed during the observation period. No variables diverged from the traditional assumptions based on the normality, multicollinearity, heteroscedasticity, and autocorrelation tests. This demonstrates that employing several linear regression equation models, the given data met the requirements. The variables of company size, company growth, effective tax rate, and business risk do not have a substantial effect on capital structure, according to this study. Capital structure is influenced by profitability, asset structure, and liquidity.
\end{abstract}

\section{Introduction}

In increasing the competitiveness of a

Competitive competition with the increasing years in the era of globalization in the world and the sophistication of technology in this era, makes companies around the world have a goal to earn profits and increase company value (Damayanti, 2013). In addition, the company must have capital in order to live and develop its business so that it can finance all company operations. company's economic growth rate, Indonesia must be able to overcome all challenges, due to the faster pace of economic growth in manufacturing companies in various sectors. In addition, companies must be required to be able to see the situation that will occur, this can reduce risk. Companies must also be able to carry out good management functions, namely in the fields of marketing, production, human resources, and finance so 
that the company's condition is healthy and superior in the competition faced in this era of globalization (World Bank).

In the context of companies that want to develop their business, companies must require sufficient capital. In meeting capital, companies can obtain capital through funding activities, this is the main activity of the financial manager function (Sartono, 2010). When making funding or capital structure decisions, the company's key responsibility to financial managers is to make a financial decision connected to the composition of debt that must be employed by the company and will effect the company's operational activities to the risks detected in the firm. In addition, the type of funding chosen must influence the company's investment decisions (Brigham \& Houston, 2006).

The Debt to Equity Ratio (DER) is a comparison of the company's total debt with its own capital that can be used to determine capital structure. Because the use of debt as a source of funding is much greater than the company's own capital, the greater the DER, the greater the risk that the company must face (Fahmi, 2012).

The Debt to Equity Ratio (DER) is a comparison of the company's total debt with its own capital that can be used to determine capital structure. Because the use of debt as a source of funding is much greater than the company's own capital, the greater the DER, the greater the risk that the company must face (Firnanti, 2011).

There are capital structure guidelines, one of which is the vertical capital structure guidelines. The guidelines for the vertical capital structure provide a ratio limit that must be maintained by a company regarding the amount of loan or debt capital with the amount of its own capital (Julita, 2013). Based on the assumption that healthy spending must initially be built on the basis of own capital, the capital structure guidelines stipulate that the amount of loan or debt capital in a company under any circumstances should not exceed the amount of its own capital (Nurmadi, 2013). The debt coefficient, which is the ratio between the amount of foreign capital or debt with own capital, must not exceed 1:1. In essence, the optimal capital structure must prioritize the interests of shareholders. Therefore, companies should fund their business with their own capital (YB \& Bambang, 2010).

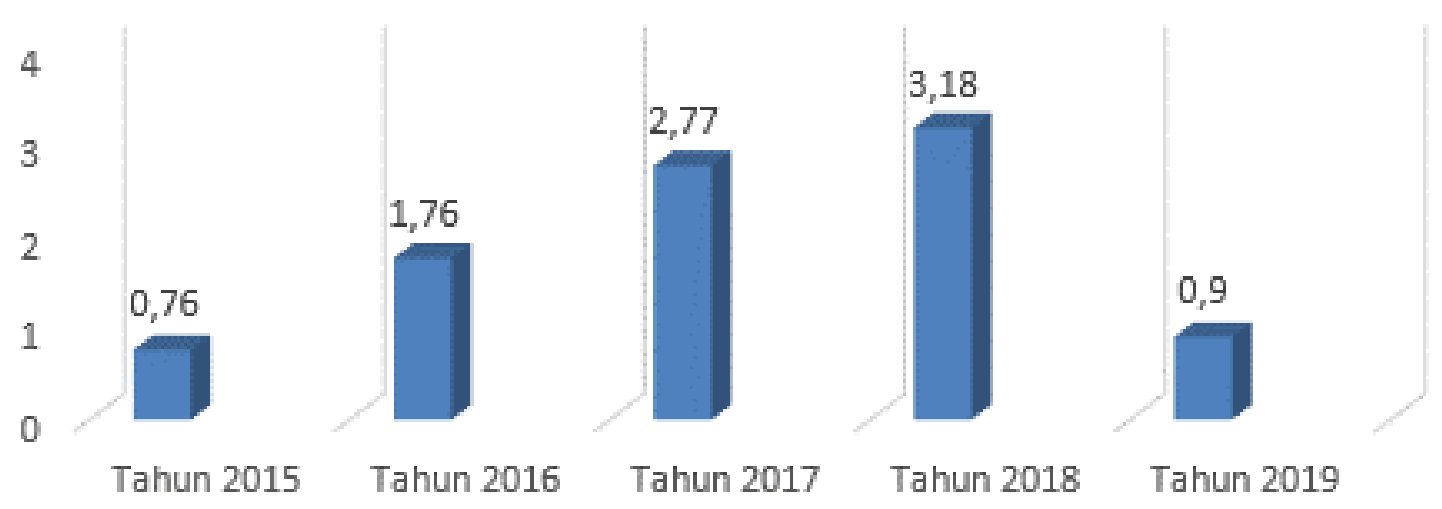

Figure 1

Movement of Debt Equity Ratio (DER) Value Increases from 2016-2018 in
Manufacturing Companies on the Indonesia Stock Exchange for the 2015-2019
Period

In the picture above shows the DER value has increased from 2016 2018 manufacturing companies listed on the IDX are above one. The average debt to equity ratio for 2016 is $1.76 \%$; in 2017 by $2.77 \%$; and in 2018 it was 
$3.18 \%$. Researchers Brigham and Houston (2011), suggest that if an organization that has a DER value exceeds the value of one, then the company uses corporate debt as its operational activity is greater than the amount of its own capital. "This is contrary to the optimal capital structure theory, which states that debt should not exceed a company's own capital." However, "many investors are more interested in companies that invest their capital in the form of investments in companies that have a DER whose value is less than one." (Listijowati, 2012).

Amiriyah and Andayani (2014) stated "The greater the capital structure ratio indicates the greater the number of long-term loans, which causes more part of operating profit to be used to pay fixed interest expenses, and more cash flow is used to pay loan installments. This will result in a decrease in the amount of net profit after tax that will be obtained by the company (Alipour, Mohammadi, \& Derakhshan, 2015).

Many studies have looked at the impact of various factors on capital structure, but the results haven't always been consistent. The researcher intends to select the factors that are considered dominant in influencing the capital structure based on this research. Profitability, company size, company growth, asset structure, liquidity, effective tax rate, and business risk will be raised in this study to analyze the effect of capital structure on these aspects with samples from the IDX in Manufacturing businesses from 2015 to 2019.

In general, investors who are long-term oriented are not so affected by market issues, because they have carried out a fundamental analysis of the company chosen to invest. in contrast to investors who are shortterm oriented. Investors that are shortterm oriented tend to follow market trends; when stock prices fall, they opt to purchase, and when stock prices rise, they decide to sell. The application of psychology to financial decisionmaking and financial markets is known as behavioral finance. Behavioral finance is a psychologically based framework that transforms the financial paradigm (Shefrin, 2010). According to Statman (1999) quoted by Chandra (2012)

According to Kole and Dijk (2010) in Ramadhan (2016), in the financial market that many investors have the same expectations, at the same time, on future prices and yields. of that perception. Bullish is an up market condition characterized by positive (high) market returns. On the other hand, bearish is a downward market condition marked by negative (low) market returns. in the Composite Stock Price Index in 2013-2015 already includes bullish and bearish market conditions.

\section{Method \\ Population and Sample}

The research object population is the LQ 45 Manufacturing company listed on the IDX according to those circulated on IDX. The object of this research uses LQ 45 Manufacturing companies where the total LQ 45 Manufacturing companies are 135 . The sample selected is LQ 45 Manufacturing companies, because the IDX has the most Manufacturing companies. While the sample is part of the members of the object under study. Purposive sampling is a technique in sampling with the type of judgment sampling. What is meant by judgment sampling is a research that needs to be done first by considering a 
research objective or problem in which the research must be developed (Felicia \& Saragih, 2015).

This research must have a characteristic which is different from previous research, namely:

1. LQ 45 Manufacturing Company according to IDX data for 2015-2019. In addition, the IDX recorded that it published complete financial reports from 2015-2019 in a row.

2. LQ 45 Manufacturing Company that always earns profit during the 20152019 period.

Criteria Companies have a number of samples in the study as many as 27 companies. Pooled data used in this study using 135 data observations (5 years $\times 27$ companies).

\section{Results And Discussion}

\section{A. Overview of the Samples Used}

The sample used in this study is the LQ 45 Manufacturing Company for the 2015-2019 period on the condition that the company has a positive profit. Retrieval of data related to the data related to this research was obtained from the IDX website, namely www.idx.co.id. Details of the number of sample companies required are 27 companies that have previously been observed with data specifications.

Table 1

Sample Details

\begin{tabular}{lc}
\hline \multicolumn{1}{c}{ Information } \\
\hline $\begin{array}{l}\text { LQ 45 Manufacturing } \\
\text { Company listed on IDX } \\
\text { 2015-2019 }\end{array}$ \\
\hline \multicolumn{2}{c}{ Sample } \\
\hline 5 years sample $=5 \times 27$ & 135 \\
\hline
\end{tabular}

Source: IDX processed by researchers (2021)

Based on the sample details in table 4.1 for the 2015-2019 period, from the data that the author studied, it was obtained as many as $27 \times 5=135$ LQ 45 manufacturing companies.

\section{B. Data Test Results}

\section{Descriptive Statistical Analysis}

The following is a descriptive statistical analysis on a sample of LQ 45 Manufacturing companies in each year.

\begin{tabular}{|cccccccc|}
\hline X1_DER & X2_ROA & X3_SIZE & X4_SAGR & X5_SA & X6_WCR & \multicolumn{1}{c|}{ X7_ETR } & Y_COND \\
1.891438 & 0.093653 & 18.01675 & 0.031643 & 0.265195 & 0.067172 & 0.261387 & 0.027319 \\
0.974679 & 0.058533 & 17.93333 & 0.055471 & 0.246216 & 0.069877 & 0.249363 & 0.013101 \\
11.39583 & 0.657855 & 20.98324 & 2.557146 & 1.000000 & 0.476512 & 1.000000 & 0.353655 \\
0.135246 & -0.006961 & 15.17374 & -0.696754 & $1.31 \mathrm{E}-05$ & -2.969182 & -0.793678 & 0.001398 \\
1.997509 & 0.108346 & 1.474015 & 0.385344 & 0.213404 & 0.324166 & 0.193922 & 0.047733 \\
1.910073 & 2.464308 & 0.345488 & 2.031821 & 0.796932 & -6.077380 & 0.779715 & 5.099028 \\
7.608784 & 10.01628 & 2.440826 & 15.64901 & 3.076502 & 58.19404 & 14.86521 & 32.87454 \\
& & & & & & & \\
201.5685 & 413.5467 & 4.444448 & 992.8723 & 14.32269 & 17966.93 & 805.5849 & 5605.247 \\
0.000000 & 0.000000 & 0.108368 & 0.000000 & 0.000776 & 0.000000 & 0.000000 & 0.000000 \\
& & & & & & & \\
255.3442 & 12.64310 & 2432.262 & 4.271760 & 35.80134 & 9.068172 & 35.28728 & 3.688050 \\
534.6656 & 1.573013 & 291.1446 & 19.89767 & 6.102542 & 14.08121 & 5.039173 & 0.305316 \\
135 & & & & & & 135 & 135 \\
\hline
\end{tabular}

\section{Figure 1}

Descriptive Statistics of Variables

Source: Processed secondary eviews data (2021)

\section{Chow Test (Chow Test)}

Redundant Fixed Effects or Likelihood ratio (Chow Test). Chow test is used to determine whether the selected model is pooled least square or fixed effects. HO is rejected if the value of the probability $F$ is less than alpha, which is less than 0.05 , where $\mathrm{HO}$ is the pooled least squares model and $\mathrm{H} 1$ is the fixed effects model. If the prob value. Cross-section chisquare $<0.05$ then we will choose a fixed effect. 


\begin{tabular}{l} 
Effects Test \\
\hline \hline Cross-section $\mathrm{F}$ \\
Cross-section Chi-square 2 \\
\hline \hline
\end{tabular}

\section{Hausman Test (Hausman Test)}

The Hausman test is a test used to see whether fixed effects or random effects are

the best method. If the Hausman test accepts $\mathrm{H} 1$ or $\mathrm{p}$ value $<0.05$, the method we choose is fixed effect.

\begin{tabular}{llll}
\hline Test & Chi-Sq. & Chi-Sq. & Prob. \\
Summary & Statistic & d.f. & \\
\hline Cross- & 7.555909 & 7 & 0.3734 \\
section & & & \\
random & & & \\
\hline
\end{tabular}

Output Interpretation:

Prklypothesis:

\begin{tabular}{cl} 
d.f. & Prphypothesis: \\
\hline 6,101$)$ & 0.6480
\end{tabular}

26 0.36th : The model follows the fixed effects

Based on the results of the Hausman test showing a significance value of 0.3734 (significance > 0.05), then $\mathrm{HO}$ is rejected and $\mathrm{H} 1$ is accepted, so it can be interpreted that the random effects model is better than the fixed effects model.

\section{Langrange Multiplie (LM)}

Langrange Multiplier (LM) is a test to determine whether the right model is used by random effects or common effects. This test was developed by Breusch Pagan. The Breusch Pagan method for the random effect significance test is based on the residual value of the OLS method.

If the $p$ value is greater than 0.05 then accept $\mathrm{HO}$ which means the best estimation method is the common effect.

\section{Langrange Multiplie (LM)}

\begin{tabular}{lccc} 
& \multicolumn{3}{c}{ Test Hypothesis } \\
& Cross-section & Time & Both \\
\hline \hline Breusch-Pagan & $\begin{array}{c}0.628507 \\
(0.4279)\end{array}$ & $\begin{array}{l}0.068893 \\
(0.7930)\end{array}$ & $\begin{array}{l}0.697399 \\
(0.4037)\end{array}$ \\
& -0.792784 & 0.262474 & -0.374986 \\
Honda & $(0.7860)$ & $(0.3965)$ & $(0.6462)$ \\
& & & \\
King-Wu & -0.792784 & 0.262474 & -0.045134 \\
& $(0.7860)$ & $(0.3965)$ & $(0.5180)$ \\
Standardized Honda & -0.621852 & 0.554746 & -4.495215 \\
& $(0.7330)$ & $(0.2895)$ & $(1.0000)$ \\
Standardized King-Wu & -0.621852 & 0.554746 & -3.004999 \\
& $(0.7330)$ & $(0.2895)$ & $(0.9987)$ \\
Gourieroux, et al. & - & & 0.068893 \\
& & & $(0.6380)$
\end{tabular}

Output Interpretation:

Hypothesis: 
HO : Common Effects

H1 : Random Effects

The Breush-Pagan (BP) probability value of 0.0000 is shown in the output results above. If the Breush-Pagan (BP) probability is greater than alpha $(0.0000>0.05), \mathrm{H} 0$ is rejected and $\mathrm{H} 1$ is accepted, implying that random effects is the correct model in the preceding results.

\section{Normality test}

"This study uses statistical analysis with the Kolmogorov-Smirnov test". Can be seen in Table 4 Variable Normality Test

Table 4

Variable Normality Test One-Sample Kolmogorov-Smirnov Test

\begin{tabular}{llr}
\hline \multicolumn{2}{c}{ One-Sample Kolmogorov-Smirnov Test } \\
\hline $\mathrm{N}$ & \multicolumn{1}{c}{$\begin{array}{c}\text { Unstandardized } \\
\text { Residual }\end{array}$} \\
\hline Normal Parameters & \\
& & 135 \\
\cline { 2 - 3 } & Mean & .027 \\
\cline { 2 - 3 } & Std. Deviation & .041 \\
\cline { 2 - 3 } & Absolute & .031 \\
\cline { 2 - 3 } & Positive & .031 \\
\cline { 2 - 3 } & Negative & -.080 \\
\hline Kolmogorov-Smirnov Z & & 3.688 \\
\hline Asymp. Sig. (2-tailed) & & .000 \\
\hline
\end{tabular}

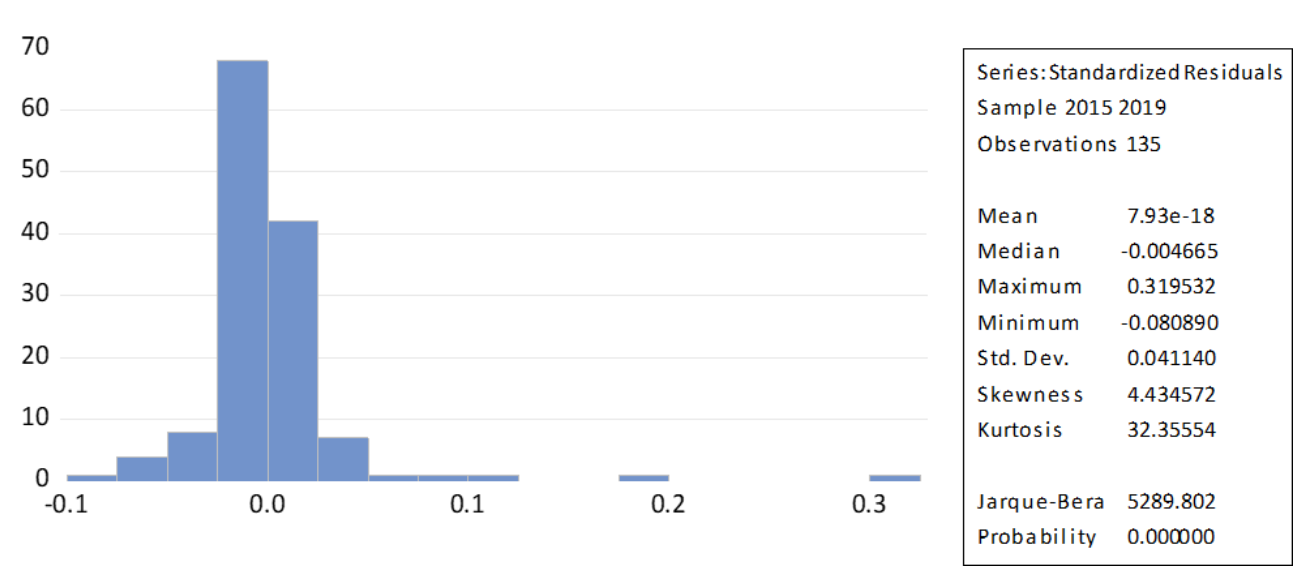

Table 4 shows that the Kolmogorov-Smirnov statistical test has a value of 0.263 and is not significant, indicating that the "Asymp Sig. (2tailed) of 0.000 is smaller than $0.05 . "$ The normal distribution residual data is then rejected, indicating that the residual data is not normally distributed.

\section{Multicollinearity Test}

"Multicollinearity testing can be seen from the tolerance value and Variance Inflation Factor (VIF)".

\section{Multicollinearity Test with VIF} Coefficientsa 


\begin{tabular}{|c|c|c|c|c|c|c|c|c|}
\hline & Y_COND & XI_ROA & $\mathrm{X}_{-}$SIZE & X3_SAGR & XA_SA & X5_WCTA & X6_ETR & X]_RISK \\
\hline Y COND & 1.000000 & 0.163018 & 0.440574 & $=0.203430$ & .0 .215912 & 0.239058 & 0.023217 & $=0.005722$ \\
\hline $\bar{X} \bar{I}_{\text {_ROA }}$ & -0.163018 & 1.000000 & .0256555 & 0.593188 & 0.330486 & -0.552646 & .0293811 & 0.155254 \\
\hline X_SIZE & 0.440574 & -0.256555 & 1.000000 & -0.509156 & .0003283 & 0.251113 & 0.053656 & .0061029 \\
\hline$X 3$ SAGR & 0.203430 & 0.593188 & .0 .509156 & 1.000000 & 0.181985 & 0.329756 & 0.186330 & 0.239868 \\
\hline X4_SA & -0215912 & 0.330486 & .0003283 & 0.181965 & 1000000 & 0230203 & -0.150410 & 0.013990 \\
\hline X5 WCTA & 0.239058 & .0 .552646 & 0.251113 & -0.329756 & .0230203 & 1000000 & 0.183554 & .0080434 \\
\hline XB_ETR & 0.023217 & 0.293811 & 0.053656 & 0.188330 & 0.150410 & 0.183554 & 1.000000 & .0019055 \\
\hline XI_RISK & -0.005722 & 0.155254 & .0061029 & 0.239868 & 0.013990 & -0.080434 & .0019055 & 1000000 \\
\hline
\end{tabular}

Figure 4

Source: Eviews 11 secondary data processed in 2021

According to table 5, the tolerance value computation yields no independent variables with tolerance values less than 0.10 , indicating that there is no connection between independent variables with values more than 0.950 . The VIF calculation's findings are also no greater than a value of ten. As a result, there isn't any multicollinearity.

\section{Conclusion}

The conclusion that the author can draw in chapter four, namely the results and discussion is that the research data has a normal distribution, there is no multicollinearity, there is no autocorrelation, and there is no heteroscedasticity. in addition, there are three hypotheses that pass (accept) from the seven hypotheses given. the following are the details of the seven hypotheses of this research:

"If the roa variable has a significant and negative effect on the debt to equity ratio, then the first hypothesis is accepted," asserts the first hypothesis.

"The size variable has no significant and negative effect on the debt to equity ratio, so the second hypothesis is rejected," asserts the second hypothesis.

"The sagr variable has no substantial and positive effect on the debt to equity ratio, hence the third hypothesis is rejected," asserts the third hypothesis.

"If a variable has a significant and negative effect on the debt to equity ratio, then the fourth hypothesis is accepted," asserts the fourth hypothesis.

"The wcta variable has no substantial and positive effect on the debt to equity ratio, hence the fifth hypothesis is adopted," asserts the fifth hypothesis.

"If the etr variable has no significant and positive effect on the debt to equity ratio, then the sixth hypothesis is accepted," asserts the sixth hypothesis.

"The risk variable has a significant and negative effect on the debt to equity ratio, so the seventh hypothesis is rejected," asserts the seventh hypothesis.

\section{References}

Alipour, Mohammad, Mohammadi, Mir Farhad Seddigh, \& Derakhshan, Hojjatollah. (2015). Determinants of capital structure: an empirical study of firms in Iran. International Journal of Law and Management. Google Scholar

Brigham, Eugene F., \& Houston, Joel F. (2006). Fundamentals of Financial Management: Dasar-Dasar Manajemen Keuangan. Google Scholar

Brigham, E. F., dan Joel, F. H. 2011. DasarDasar Manajemen Keuangan. Jakarta: Salemba Empat Google Scholar

Brigham, Eugene F. dan LC. Gapenski. 1996. Intermediate Financial Management. Fifth Edition New York: The Dryden Press. Google Scholar

Damayanti. (2013). Pengaruh Struktur Aktiva, Ukuran Perusahaan, Peluang Bertumbuh 
dan Profitabilitas terhadap Struktur Modal (Studi pada Perusahaan Farmasi yang Terdaftar di Bursa Efek Indonesia). Jurnal Prespektif Bisnis, Vol. 1, No. 1. Google Scholar

Fahmi, Irham. (2012). Analisis Kinerja Keuangan: Panduan bagi Akademisi, Manajer, dan Investor untuk Menilai dan Menganalisis Bisnis dari Aspek Keuangan. Google Scholar

Felicia, Felicia, \& Saragih, Ferdinand D. (2015). Analisis pengaruh market timing terhadap struktur modal perusahaan non-keuangan yang terdaftar di Bursa Efek Indonesia. Jurnal Administrasi Bisnis, 11(2). Google Scholar

Firnanti, Friska. (2011). Faktor-faktor yang mempengaruhi struktur modal perusahaan manufaktur di Bursa Efek Indonesia. Jurnal Bisnis Dan Akuntansi, 13(2), 119-128. Google Scholar

Julita. (2013). Pengaruh Profitabilitas dan Tingkat Pertumbuhan Penjualan Terhadap Struktur Modal Pada PT. Perkebunan Nusantara III (Persero) Medan. Jurnal Manajemen. 1 (10), pp: 18-19. Google Scholar

Listijowati, H., dan Agathi, A. 2012. Analisis
Faktor-Faktor Internal Perusahaan yang Mempengaruhi Struktur Modal Pada Sektor Barang Konsumsi. Skripsi. Universitas Kristen Satya Wacana. Google Scholar

Nurmadi, R. (2013). Analisis faktor-faktor yang mempengaruhi struktur modal perusahaan manufaktur. Jurnal Keuangan Dan Bisnis Vol. 5(2): 13-25 Google Scholar

Sartono, A. (2010). Manajemen Keuangan (Teori dan Aplikasi). Edisi Keempat. Penerbit BPFE. UGM. Yogyakarta Google Scholar

Shefrin, Hersh. (2010). Behavioralizing finance. Now Publishers Inc. Google Scholar

YB, Gunawan Sugiarta, \& Bambang, Riyanto. (2010). Feature level fusion of speech and face image based person identification system. 2010 Second International Conference on Computer Engineering and Applications, 2, 221225. IEEE. Google Scholar

World Bank. (n.d.). Retrieved Januari 22, 2014,fromhttps://www.Worldbank.Org/I $\mathrm{n} /$ Country/Indonesia

\section{Copyright holder :}

Theresalin, I Gusti Ketut Agung Ulupui, Harya Kuncara (2022)

First publication right :

Journal of Social Science

This article is licensed under:

(cc) (i) 